\title{
Representative Library Collections as a Response to the Institutional Oppression of LGBTQ Youth of Color
}

\author{
Jeanie Austin, San Francisco Public Library, USA
}

\begin{abstract}
Lesbian, gay, bisexual, transgender, and queer (LGBTQ) youth of color are frequently subject to forms of institutional oppression that shape their lives. Institutional forces are rarely mentioned in research on library services to youth. This project examines one possibility for creating more meaningful library services that acknowledge how state power and publishing trends limit access to meaningful representation for LGBTQ and gender non-conforming youth of color. It begins with the synthesis of ongoing campaigns for greater diversity in young adult literature; critical theoretical approaches to race, gender, and sexuality; and the needs identified by adults working for a critically situated community drop-in youth center for LGBTQ youth. Using a case study set in Oakland, California, the research focuses on how representative library materials might be positioned in culturally sensitive community spaces as one way to address the histories of exclusion and invisibility that have informed public library practice in the U.S.
\end{abstract}

Keywords: institutional oppression; LGBTQ; representation; young adult librarianship; youth of color

Publication Type: case study

\section{Introduction}

nstitutional oppression sets the boundaries of whether or not youth of color and/or lesbian, gay, bisexual, transgender, and queer (LGBTQ) and gender non-conforming youth will encounter representative materials and personally relevant information. Youth belonging to these groups must often route around traditional contexts, such as schools or libraries, to locate books that contain representative characters, scenarios, or culturally relevant themes. Difficulties in locating representative texts go beyond the issues of their invisibility in public library collections. Structural forces, such as low levels of diversity in publishing (WeNeedDiverseBooks, n.d.); the institutional devaluing of youth's understandings of themselves, which is particularly true for Black girls (Morris, 2016); cultural norms of libraries and the selective enforcement of these norms (Austin, 2018); and the stress of consistent and ongoing policing and surveillance in schools and communities create additional and ongoing barriers for youth who do not often encounter meaningful representations of their experiences or identities in day-to-day contexts.

This case study delves into how librarians can use critical theoretical approaches to carceral practices and institutionalized oppression to create broadly defined representative materials. It investigates how LGBTQ and gender non-conforming youth of color are heavily scrutinized in schools, communities, and public spaces, while being simultaneously obscured in young adult (YA) literature (Cart \& Jenkins, 2015; Hunt \& Moodie-Mills, 2012; Spade, 2011; Stanley \& Smith, 
2011; Winn, 2011). In the context of developing a representative collection-one that broadly reflects the lives and identities of LGBTQ youth of color-this case study argues for the importance of recognizing the presence of youth made vulnerable to and by the state. This discussion is important not only because it addresses a gap in YA collection development, which rarely incorporates the broadly diverse and complex representations of youth, but also because it situates this collection in a culturally sensitive location run by culturally competent adult mentors who recognize how institutional oppression shapes the information made available to youth (Cooke, 2017). Systems of policing, surveillance, and scrutiny lead to the removal of youth of color and/or LGBTQ and gender non-conforming youth from their own communities through incarceration and other forms of violence, while the publishing system invisibilizes them or presents them as stereotypes in the texts that become foundational for many youth as they develop understandings of their lives. The described case study is an example of how librarians can work to address mutually reinforcing systems of policing and publishing by taking action to ensure a radical and vast presence of identities and experiences.

This paper briefly highlights information on the policing of LGBTQ and gender non-conforming youth of color; covers some of the existing research and activism related to increasing representation in books for YA; and offers a description of the Queer and Trans Youth Treehouse (QTY Treehouse), a non-profit-funded drop-in youth center, as a frame for the creation of a broadly diverse library collection focused on the experiences of LGBTQ and gender nonconforming youth of color. It acknowledges the present state of power structures that shape the lives of youth, while also imagining alternative structures that are not likely to become yet another extension of institutional oppression.

\section{Institutional Oppression and Representative Materials}

The definition of institutional oppression presented in this research is informed by critical theoretical perspectives. It recognizes that institutions of incarceration, schooling, and even libraries collectively work in the ways that often foreclose possibilities for large groups of youth. The likelihood of imprisonment and the ensuing consequences thereof shape the experiences of people of color and/or LGBTQ and gender non-conforming individuals in the U.S. (Davis, 2003; Hunt \& Moodie-Mills, 2012; Winn, 2011). These groups are not only more likely to be targeted for direct confrontation by police; they are also often continuously excluded by the system while their access to resources, such as education, housing, employment, and mainstream cultural belonging, is denied or limited (Spade, 2011; Stanley \& Smith, 2011). Youth of color are more likely to be seen as disruptive by teachers and library staff than their white counterparts, which is also true with regard to LGBTQ and gender non-conforming youth (McCurdy, 2014). Youth of color and/or LGBTQ and gender non-conforming youth are also more vulnerable within the school system and institutions of power and often become a subject of detention, suspension, expulsion, Individualized Education Plans (and mental health stigma), peer violence, and many other forms of oppression (Meiners, 2007). Theorists have noted that this vulnerability is used to track youth of color and/or LGBTQ and gender non-conforming youth into prison and other institutions that, as Alexander, Spade, and others above illustrate, offer little in terms of redemption or opportunities to escape cycles of oppression (Meiners, 2007; Osher, Quinn, Poirier, \& Rutherford, 2003; Skiba, Michael, Nardo, \& Peterson, 2000; Wald \& Losen, 2003).

The lack of representative materials for children and youth is not a new discussion in librarianship; it was highlighted in popular press in Larrick's article "The All-White World of Children's Books," published in 1965. Some increase in diverse publishing has occurred in the

The International Journal of Information, Diversity, \& Inclusion, 3(1), 2019

ISSN 2574-3430, https://jps.library.utoronto.ca/index.php/ijidi 
time between Larrick's publication and the present, but progress has often been slow, sporadic, or influenced by social and political tides around racial diversity (Harris, 2003; Lo, 2014, 2015; Sims, 1982). Discussions of representation do not always address the long histories of library services to youth and the ways in which they perpetuate existing social structures or histories of institutional racism in the library (Cai, 2002; Schlesselman-Tarango, 2016). However, these histories not only impact the lives of youth, they also shape whether, how, and in what ways library services perpetuate, challenge, or interrupt existing social inequalities; whether or not libraries reinstitute racism and homophobia through assumptions of moral uplift and exclusion; and how librarians can work against easy solutions to complex problems while still engaging in day-to-day activities with youth (Mehra, 2015; Montague, 2015; Schlesselman-Tarango, 2016).

At the same time, representation does require access to materials and media that reflect youth's lives, legitimize their life experiences rather than Othering them, and which provide them with an access point of identification (Naidoo \& Dahlen, 2013). Access points are not limited to mainstream television and publications. They may include encounters with or knowledge of youth organizations, community networks, and spaces for association with others who have similar experiences of being targeted by the state (Bernstein, 2014). The necessity of materials that do not reiterate the dominant narratives of white, middle-class, heterosexual, and cisgender American values has been deeply embraced in relation to narratives of representation and Othering, as is exemplified by the ongoing \#WeNeedDiverseBooks campaign, founded in 2014 (http: // weneeddiversebooks.tumblr.com/).

Questions related to access to representative materials and the recognition of institutional oppression in youth lives framed how a library collection was developed at the QTY Treehouse. The library collection was designed to fit with already existing services and the intentions of the adult staff that maintained the space. At the time of this research, the QTY Treehouse, a storefront drop-in center for LGBTQ and gender non-conforming youth, was providing a variety of resources and programs for youth. Staff at the center also conducted outreach in the community and led in-school groups across Oakland. The establishment of the library in a situated LGBTQ and gender non-conforming space, which was culturally conscious of youth of color, acted as a model for the application of critical theory to working with youth who were made vulnerable to and by the state-LGBTQ and gender non-conforming youth of color-can inform needed services in the larger community.

\section{Critically Approaching Library Service for LGBTQ and Gender Non-Conforming Youth of Color}

Research on public library collections, services, and programming for LGBTQ and gender nonconforming youth often highlights a lack of knowledgeable resource provision. Curry's work on insufficient training among libraries responding to reference questions from gay youth in the U.K. gives a striking example (2005). Some public librarians did not even uphold the standards of patron privacy when responding to gay youth, and even when they did, they often did not have critical awareness of relevant resources for youth. In the time between Curry's publication and the present, numerous studies and resources have been created to encourage and support librarians in the provision of public library services to LGBTQ youth (Cart \& Jenkins, 2015; Kurz, 2018; Mehra, 2011; Mehra \& Braquet, 2011). Some of these authors have focused on how LGBTQ and gender non-conforming youth's experiences of institutional oppression, including homelessness, shape the information youth desire and their relationship to the public library (Shelton \& Winklestein, 2014). For example, Robinson (2016) focuses on how systemic forces are

The International Journal of Information, Diversity, \& Inclusion, 3(1), 2019

ISSN 2574-3430, https://jps.library.utoronto.ca/index.php/ijidi 
perpetuated in the library, through low awareness and insufficient research in the field, bringing about the exclusion of LGBTQ cultural knowledge and curtailing the meaningful library use by LGBTQ patrons.

The same need for cultural competence has been identified in the context of library services for racialized youth. Cooke (2017), Roberts and Noble (2016), Sims Bishop (1990), Tatum (2006, 2008), and others advocate for more informed, meaningful, and socially and politically aware services to diverse patron groups. Their research intersects with research on library services to LGBTQ youth in calling for critically positioned library services. The QTY Treehouse was chosen as a case in point because its services aligned with needs and competencies identified in library and information science research. Its emphasis on cultural knowledge, lived experiences, and providing information specific to LGBTQ and gender non-conforming youth of color illustrated the cultural sensitivity of the space.

Critical approaches on the part of adults involved in the administration of the QTY Treehouse ensured that the creation of the library would be a collaborative process. The QTY Treehouse library became a partnership between the QTY Treehouse staff and me. Our partnership spoke to the possibility of combining representative collections and culturally aware library services (Cooke, 2017). It resisted powerful forces that shape available representations for youth by placing YA texts in in a meaningful context that centered on the experiences of queer and transgender youth of color.

My previous studies involving the statements and writings of youth located in juvenile detention facilities led me to pursue this project in partnership with one of the adult coordinators at the QTY Treehouse (referred to as " $\mathrm{B}$ " in this article) through a participatory action research framework. Shared inquiry led to the creation of specific categories for inclusion in the library collection along the lines of multiple understandings of meaningful representation. Our process involved going beyond traditional collection development procedures to incorporate online user reviews and to determine when and whether identities were meaningfully developed in YA texts.

In the earliest stages of the research, B and I held the shared goal of identifying texts that could form a broadly representative library collection that prioritized LGBTQ and gender nonconforming youth of color. Drawing from our own experiences with the lack of representative materials, we tried to construct a collective sense of shared identities and to develop an understanding of institutional oppression. We also worked to identify materials that broadly included the experiences and identities of youth of color and/or LGBTQ and gender nonconforming youth from a variety of backgrounds. An important consideration was soliciting feedback from youth about the texts that resonated with them and spoke to their own experiences. Youth had the option of providing reviews. Although few young people took advantage of this option, at the end of this research project, B and I agreed that the library was a meaningful part of the drop-in center services. One of the library collections distinct features was the emphasis on the whole of the youth experience, which contrasted with the more commonly seen focus on deficit-focused models and presumptions of youth's lack of knowledge or skills. Given the dearth of formal feedback from youth, the success of the library collection is illustrated through the organic incorporation of the library collection into the overall function of the community-based youth drop-in center.

\section{QTY Treehouse}

The QTY Treehouse, located in West Oakland, is an open-hours after school and summer

The International Journal of Information, Diversity, \& Inclusion, 3(1), 2019

ISSN 2574-3430, https://jps.library.utoronto.ca/index.php/ijidi 
community drop-in center for LGBTQ youth of color. West Oakland was, at the time of this research, a home for the Black majority population in the area of Oakland; it was also the former home of the Black Panthers ${ }^{1}$. The QTY Treehouse was one of the few queer youth spaces located in Oakland that had existed for over three years, and the only long-running youth center specifically dedicated to queer youth in Oakland. Other non-profit youth centers in Oakland, such as Youth Uprising!, were located in East Oakland and provided queer youth and ally programming; however, they were not established as spaces dedicated only and specifically to LGBTQ and gender non-conforming youth. The De Colores group, while composed of specifically LGBTQ and gender non-conforming people of color, focused services on young people of 18 years and older. Other well-established LGBTQ centers in Alameda County included the Pacific Center in Berkeley, CA and OURSpace in Hayward, CA. There were also numerous LGBTQ youth programs and dedicated spaces in San Francisco, CA.

A wealth of services does not necessarily mean that youth can access these services (due to costs of transportation) or that the services offered include an understanding of LGBTQ and gender non-conforming youth of color identity. The QTY Treehouse met an existing need. Originally located in downtown Oakland, the QTY Treehouse opened in November of 2012 with performances that coded the identity of the LGBTQ and gender non-conforming youth of color. Voguing and youth drag occurred alongside a DJ who co-founded an Oakland queer nightlife institution Ships in the Night (Phaneuf, 2012). Even at its inception, the QTY Treehouse was envisioned as a space in which youth-created media would be an aspect of the center.

At the time of this project, the drop-in youth center sat near the last BART station between Oakland and San Francisco, in an area that was once a booming Black business strip. The space was now a line of open and closed storefronts, trailing toward a residential area in the direction of the Port of Oakland. The QTY Treehouse was located in one of the last buildings closest to the residential area. The windows of the QTY Treehouse held a large pink decal and an organization logo that incorporates the City of Oakland oak tree (with a symbolic treehouse), mirrored roots and branches, and a rainbow. The decal was indicative of the organizational purpose as a space for queer and transgender youth, but the youth could only be identified when they enter or leave the building; otherwise, the windows were covered in black fabric to protect privacy. Inside, the QTY Treehouse had two large rooms, a small room utilized by staff as a workspace, and a clothing closet. In addition to the library collection and drop-in hours, the QTY Treehouse provided sex education resources and various discussion groups, and employed well-informed queer and transgender adult staff who were, at the time of this research, people of color and who acted as mentors and role models for the youth that utilized the space.

As with all nonprofits, funding patterns shaped the physical characteristics of the QTY Treehouse (Kwon, 2013). Funding for the QTY Treehouse, which functioned under the umbrella of Health Initiatives for Youth (HIFY), originally came from a Substance Abuse and Mental Health Services Administration grant (HIFY, 2016). At its founding, the center served YA between the ages of 18 and 24. This age range was expanded in 2013 and the center relocated to West Oakland (QTY, 2013). City funding was expanded to cover additional LGBTQ youth programming in 2014 and HIFY became one of the main recipients of funds. This allowed for more open hours at the QTY Treehouse with staff present and the additional delivery of services (Bajko, 2014).

My research partnership with the QTY Treehouse was facilitated by B, a QTY Treehouse staff member. It began in the fall of 2015. At the time, the QTY Treehouse was in the middle of a major staffing shift, which resulted in a renewed commitment to services for LGBTQ and gender non-conforming youth of color in Oakland. Under the leadership, the QTY Treehouse underwent

The International Journal of Information, Diversity, \& Inclusion, 3(1), 2019 ISSN 2574-3430, https://jps.library.utoronto.ca/index.php/ijidi 
a revision to prioritize LGBTQ youth of color as central to programs and services. It was in this context that we partnered with the goal of creating a racially diverse LGBTQ and gender nonconforming YA collection.

The partnership would not have been possible had it not been for a critical approach to library services for the youth who are most likely to face institutional forms of oppression. Our shared critical approach provided a foundation for this case study and its objectives. The partnership took place through a process of shared inquiry with the goals of social change.

\section{Methodology}

The principles of participatory action research guided the case study. The approaches of staff at the QTY Treehouse and my own approach differed in implementation but overlapped in shared inquiry. My project focused specifically on policing, institutional oppression, and library practice, while the QTY coordinator focused on the role of library materials in the lives of LGBTQ youth of color from an experiential and practiced perspective. Initial planning meetings involved discussions about the role of literature in relation to understanding identities and its supporting role in creating collective change.

McIntyre (2008) describes the principles of participatory action research (PAR) as:

(a) a collective commitment to investigate an issue or problem, (b) a desire to engage in self and collective reflection to gain clarity about the issue under investigation, (c) a joint decision to engage in individual or collective action that leads to a useful solution that benefits the people involved, and (d) the building of alliances between researchers and participants in the planning, implementation, and dissemination of the research process (p. 1).

The participatory action research framework works to remedy exploitative research often conducted in vulnerable populations by seeking to create actual, responsive change that incorporates participant understandings and respects participants' knowledges and contributions. It also draws from Freire's (2008) critical pedagogical approach to learning as a process in which all parties act as teachers and learners to destabilize hierarchies established through histories of oppression. The research agenda of PAR seeks to address the historical marginalization of participants, redistributing the power between researchers and the researched so that they become co-learners. In PAR, the research is led by the needs of the groups and individuals involved, and they guide its direction, implementation, and evaluation (Bishop, Mehra, Bazzell, \& Smith, 2003). As Brown and Rodriguez (2009) state, "PAR is grounded in the epistemological belief that authentic understandings of social problems require the knowledge of those directly affected by them" (p. 1).

\section{Shared Inquiry: Parameters for Collection Development}

As mentioned above, materials for youth were initially intended to be included in the QTY Treehouse operations. At the time our partnership began, the QTY Treehouse did have a small collection of materials located on a bookshelf in a corner of the programming room. The materials in the QTY Treehouse did not communicate the depth and breadth of identities or experiences of LGBTQ and gender non-conforming youth of color, nor did they create an idea of communal experience. Our decision to update the collection and to build a more youth-focused collection was in part possible because of publishing shifts. As Cart and Jenkins (2015) trace in 
their introduction to Top 250 LGBTQ Books for Teens, the publishing of LGBTQ YA materials heavily increased during the first decade of the 2000s. However, this increase did not significantly include LGBTQ characters of color. In recognition of how institutional oppression works through forced invisibility and stereotype, the adult coordinator at the QTY Treehouse and I sought to address this shortfall through our own collection development process. Developing the library collection involved sorting through the existing materials to assess their usefulness along mutually established library collection development criteria:

1. Representative Materials. Materials were considered along three criteria: the inclusion of queer content, the racial identification of characters, and, when possible, the inclusion of transgender and gender non-conforming characters. Materials portraying experiences of LGBTQ and gender non-conforming youth of color were collected to explicitly counter the idea of the LGBTQ experience as white experience and to create a feeling of racialized queer consciousness and community (Cart and Jenkins, 2015). Due to the lack of YA materials that feature LGBTQ and gender non-conforming youth of color as main characters, books where a secondary character of color identified as LGBTQ or gender non-conforming were also identified.

2. Primarily written for YA. The QTY Treehouse served teens and YA up to the age of 24 . Creating a collection of YA materials worked to reinforce the idea of QTY as a space for queer and transgender youth. This process also challenged the boundaries of what is thought of as YA literature in library practice by expanding the traditional definition of YA literature to include more adult materials.

\section{Locating Materials}

Library materials at the existing QTY library were selected or weeded based on the above criteria. Following this, we began the process of identifying materials that fit the ultimate goals of the new collection. It was necessary to look outside of traditional selection tools in order to identify materials that fit with our criteria because professional reviews are often inconsistent in addressing diversity and do not focus sufficiently on the nuances of characters' lived experiences (Lo, 2015; Ostenson, Ribeira, Wadham, \& Irion, 2016; Roberto, 2011).

Collection development began with the selection of materials based on our personal familiarity with meaningful titles and useful resources. Among these resources were:

- Rainbow Lists compiled by the American Library Association's Gay, Lesbian, Bisexual, and Transgender Roundtable (award winners were assessed in keeping with Jiménez' 2015 analysis and critique of the lack of racially diverse and predominantly gay malecentered YA books on various award lists);

- Cart and Jenkins' Top 250 LGBTQ Books for Teens;

- We Need Diverse Books campaign (http://weneeddiversebooks.org/) and its attendant hashtag (\#WeNeedDiverseBooks);

- Diversity in YA (http://www. diversityinya.com/);

- Queer Book Club (http://queerbookclub.tumblr.com/);

- lists from the Center for Children's Books that related to diversity and sexuality; 
- Reading While Queer (http://reading-while-queer.tumblr.com/); and

- non-traditional resources such as the 'Arts and Culture' section of Colorlines (http://www.colorlines.com/categories/arts-culture).

The above resources were useful in assembling an Amazon wishlist, which became a longlist of materials for further selection or deselection. The final step of our process involved analysis of user reviews from Goodreads to assess the quality and meaningfulness of representation and lived experience within the materials on the list. User-generated reviews were used to ascertain concrete ways in which representation took place in the selected texts (Spiteri \& Pecoskie, 2016).

The QTY Treehouse staff partner and I each worked from our areas of expertise to identify the needed and available materials. As a staff person at the QTY Treehouse, and a gender nonforming artist of color, B provided important insight into daily needs, such as medical and sexual health resources, and available materials that included artistic production-including poetry, visual art, and performance. Throughout the collection development process, B emphasized the role of power in shaping available resources and the need to represent LGBTQ and gender nonconforming youth of color as more complex and richer than they are presented by the system. I drew from experience working with incarcerated youth and theoretical guidance to critically analyze books and readers' commentary about stereotypes and representation. At times, reader reviews on social media (blogs or Goodreads.com) clearly criticized specific forms of representation, leading us to view the book as unsuitable for the QTY Treehouse library collection. At other times, B and I used an intersectional analysis (Crenshaw, 1991; Collins, 2008) to weigh readers' perspectives of specific representations, or differing valuations of specific forms of representation, against the dearth of representations of youth who face oppressions that include a lack of meaningful information and portrayals of their lives.

At the completion of this research, the collection contained over 60 published titles, as well as a handful of self-published zines relating to the issues of sexuality, race, and gender. At times, materials were selected because of their content; at others, due to the racial and/or LGBTQ identification of their authors. A complete list of published titles is available in the Appendix to this article. Listed below are four exemplar texts that illustrate how the collection accounted for both racial identity and lived experience.

Little, A. (2013). Anatomy of a girl gang. Vancouver: Arsenal Pulp Press.

Anatomy of a Girl Gang was among the Top 10 selected texts on the In the Margins 2015 list (Cheney, 2015). (In the Margins is a booklist that prioritizes the input from youth living in juvenile detention facilities and is produced in collaboration with librarians who provide services in juvenile detention centers.) The book is gripping, harsh, beautiful, and brings together girls of various racial backgrounds in a story of collective attempts at survival. It also features a lesbian romance between the girl gang members. It speaks to the idea of a shared experience between characters with the recognition of their individual locations and experiences within the collective. It is street lit with a twist; the focus on young women's experiences of shared oppression leads to the formation of the Black Roses. Of course, these realities are not the only available depiction of the effects of white supremacy, racialization, criminalization, structural poverty, and individual and collective experiences therein. 
Ruff, S. S. (2008). Finlater. New York: Quote Editions.

Finlater won the 2008 Lambda Literary Award for its portrayal of the relationship between Cliffy and Noah. Finlater pushes the boundary traditionally set between adult and YA literature. In his review of the book, Reginald Harris (2010) explains this phenomenon:

A quiet revolution has occurred in fiction for and about young adults in recent years. Keeping up with changes in the larger culture, young adult authors are writing grittier works, with a greater attention to social detail, using stronger, more realistic language that might be shocking to adults who have not been paying close enough attention to the lyrics of recent pop, hip-hop and rap songs (n.p.).

Harris (2010) goes on to name one of the distinct features of this book: it depicts the experience of a Black gay young man. During the materials selection process, it became increasingly obvious that few representations of Black queerness exist in YA literature. Fortunately, a collection of essays published in 2015 was available to supplement this obvious limitation resulting from mainstream publishing practices.

Neal, J. (2015). What color is your hoodie? Essays on Black gay identity. New York: Chelsea Station Edition.

What Color is Your Hoodie? was a 2016 Lambda Literary Award finalist. The collection of essays, intended for an adult audience, covers a range of topics, creating a varied portrayal of what it is to be simultaneously Black and gay. As with Finlater, including this book in the collection aligned with the idea that libraries for youth who are most likely to experience everyday institutional oppression should recognize that, due to the limited representative portrayals of LGBTQ and gender non-conforming youth of color, only including YA categories in the QTY Treehouse library collection would have limited young people's access to important resources. YA categories are often drawn to protect youth from encountering materials that may go beyond their level of maturity, but placing a YA boundary in the QTY Treehouse collection would have prevented youth in the center from easily locating materials related to their economic experiences, their sexualities and gender identities, and how these intersect with the racialization and criminalization they faced in their day-to-day lives. Drawing from this, YA librarians may wish to consider whether or not placing inflexible and restrictive categories on YA collections serves to perpetuate whiteness, heterosexuality, cisgender privilege, and middleclass belonging under the guise of protecting youth from adult content.

Golio, L. and Scholl, D. (2014). We are the youth. New York: Space-made.

The idea of situatedness-of context and history as shaping lived experience-was heavily emphasized in the materials selected for the QTY Treehouse library. Perhaps no book in its entirety exemplifies this better than We Are the Youth. In this book, the physicality (embodiment) of youth comes through in the inclusion of photographs alongside their own essays about their identities and experiences. Here, individuality and collectivity are themes that rise and fall throughout the text. The book also stands in conversation with a central aim of this research: it focuses on queer youth expression. Blake (2015), one of the youth included in the project, shared his experience of the intersection of being Black and transgender, stating that "[b]eing a Black trans man is an especially unique experience. When you transition from any gender to another gender, that affects you. I went from a Black woman to a scary Black guy. My white trans guy friends say they get all these great privileges. I've had a lot of experiences where

The International Journal of Information, Diversity, \& Inclusion, 3(1), 2019

ISSN 2574-3430, https://jps.library.utoronto.ca/index.php/ijidi 
people look at you differently. It's scary." Blake and other youth discuss their lived experiences of race, sex, or gender identity throughout the book, creating an ongoing reflection of the diversity and similarity of experiences of being an LGBTQ or gender non-conforming youth.

Blake's essay must now be read retrospectively. He was named homecoming king at his high school in 2014 and committed suicide in 2015 (Jeltsen, 2015). Blake's experiences speak to the fact that institutional oppression directly impacts the lives of youth. This is evidenced in largescale studies of LGBTQ youth in the U.S. A 2015 poll by the Center for Disease Control revealed that nearly $30 \%$ of responding LGB youth had attempted suicide over the last year, and nearly $43 \%$ had suicidal thoughts (Kann et al., 2016). This can be taken as another sign of the ways in which LGBTQ youth are positioned within systems of power: their lives, and their deaths, are often disposable to the state.

\section{Situating Materials in the QTY Treehouse}

In 2015, when my partnership with the QTY Treehouse staff began, the existing library collection was located on shelves in a corner of the secondary room, tucked away and requiring motivated youth to seek out materials. During the course of the project, B and I worked together to create a "living room" space in the main room. We envisioned the space to be comfortable for extended use, considering that youth may only be able to read the materials in the QTY Treehouse library collection while at the community center. We recognized that in other places (e.g., home, school, or public transportation), youth's use of library materials indicating their sexuality or gender identity could place them in a precarious position. Ultimately, this led to the purchase of a long, low cubby-style bookshelf that held the new library collection. Materials were sorted into broad categories of fiction, non-fiction, graphic novels, and zines in respective cubby areas, leaving room to display books face-forward in the cubbies and on top of the bookshelf. A box for submitting review forms was also available on top of the shelf. Small decorations that signaled queerness were used to create interest and excitement around the collection. Couches and comfortable seating were placed facing from either side of the shelf, and a coffee table was positioned between the seats for the youth to use as a space to display books or work on their own projects. The physical prominence of the library collection symbolically reflected its incorporation into the overall functioning of the QTY Treehouse.

\section{Library as Identity}

Over the course of the year following the creation of the library collection, it became part of the QTY Treehouse's public image. The library collection was listed in promotional handouts among the services and resources offered by the center, and in specially created fliers made to promote the LGBTQ and gender non-conforming youth of color YA library collection. The QTY Treehouse display at the 2016 "The Time is Now!" conference is symbolic of the incorporation of the library into the youth center's overall identity and services.

The Time is Now! is a gathering of LGBTQ youth of color from across the East Bay area for a oneday conference in Oakland. The 2016 conference theme was "Thriving not Surviving." Nearly 100 youths attended or organized their own presentations and performances, workshops, and educational sessions. A variety of organizations serving LGBTQ and gender non-conforming youth were represented or had direct input to the creation of the conference (Cassell, 2016). The QTY Treehouse was also present.

The QTY coordinator transported the library collection and shelving to the conference, 
showcasing the collection rather than simply promoting it. Over the course of a full day at the conference, the entire library collection was available to attending youth for browsing and circulation. Youth and adults alike expressed excitement that the library collection had been available and commented on the diversity of the LGBTQ materials. The positive reception of the library collection spoke deeply to the results of the participatory action research project. Utilizing an informed approach to partnership and the development of mutual goals that worked to benefit the QTY Treehouse ultimately resulted in a library collection that was fully integrated into the QTY Treehouse's public image. The collection was meaningful and broadly diverse and reflective of individual experience in the context of shared and collective experiences of oppression and joy.

\section{Institutional Terrains}

Part of the success of the QTY Treehouse library must be attributed to the critical stance undertaken in this research. The adult coordinator at the QTY Treehouse and I shared a goal of creating a collection that implied individuality and collectivity in the face of state systems of control and forms of institutional oppression that shape the lives of LGBTQ and/or gender nonconforming youth of color. As a whole, the collection reflected a breadth of identities and experiences, including portrayals of strength, collectivity, activism, survival, and resistance alongside lived realities of loss, homelessness, criminality, and structures of oppression. Materials complemented each other to validate lived experiences of individuals and rally for collective change.

Just as institutional constraints shaped the materials available for inclusion in the QTY Treehouse library, they also shaped the scope of ongoing services at the QTY Treehouse. Grant funding that supported the community drop-in center shifted in August of 2016, limiting drop-in hours and access to resources, including the library collection. Funding structures for youth programs shape how and what services can be available (Kwon, 2013), and often shift quickly from one area of (institutionally-constructed) concern to another.

Additionally, the effectiveness of services to youth is often measured numerically within grant reporting procedures. In the context of youth non-profits and library services to youth, the focus on the numbers served or numbers reached overlooks the often dramatic real-life positive impact made by library services on the lives of youth of color and/or LGBTQ and gender non-conforming youth.

\section{Youth Feedback}

Despite the above constraints, the QTY Treehouse staff continued to provide drop-in hours and to enthusiastically promote the library collection at community events. Their commitment to resource availability for queer and transgender youth of color included the library materials as a central feature of situated services. Through drop-in hours and in-school groups, they continued to promote access to library materials and create possibilities for youth to provide feedback about the materials they encounter.

Youth assessments of specific materials involved the completion of half-sheet review forms that were included in each of the library materials. Youth were under no obligation to complete the forms and were informed that their responses would potentially be included in this research project. Review forms covered four general topics through open-ended prompts. 
These prompts concerned

1. Favorite parts of the book

2. Least favorite parts of the book

3. Did you relate to the book? Why or why not?

4. Kinds of books/topics that need to be further represented in the library.

Two youth review forms are highlighted to convey the way that youth identified complex relationships with, and understandings of, their lived identities, their evaluations of representation, and the affective aspects of encountering representations that they found meaningful. Youth evaluations are presented here in full.

Neal, J. (2015). What color is your hoodie? Essays on Black gay identity. New York: Chelsea Station Edition. (described above).

My favorite part of the book was Neal's ideas on his intersectional identity and how that impacted his experiences as a professor, writer, and husband. Neal wrote a lot about his Black gay identity, and as someone who shares a similar identity, it was affirming.

My least favorite part of the book was Neal's analysis on porn, while it did touch on Black men and stereotypes it lost my attention by being too detailed in listing specific porn stars and movies.

Overall, I related to the author's stories and opinions because we share similar identities but his ideas and voice came from the lens of someone who has achieved higher education which I didn't relate to.

The kinds of books I would like to see in the library are on non-fiction qtpoc (queer and trans people of color) history. I would like to see books that come from legends and icons in qtpoc history.

Beier, E. (2016). I like your headband. Publisher: Author.

"Everyone has a first crush story-this is mine. Black and white, sixty four pages perfect bound. Cameos from Sailor Moon and Destiny's Child" (Beier, n.d.).

I Like Your Headband is not described as an example text because it lacks non-white racial representation. It was included in the collection not only because it ties an experience of young bisexuality (a category Jiménez, 2015, notes as missing from the Lambda and other lists), but also because it is by an award-winning comic who also creates anti-racist posters and art. I Like Your Headband tied with another comic to receive the Prism Queer Press Grant in 2016. Elizabeth Beier (the author) is from Oakland and was the 2017 chair of the Prism Queer Press Grant.

This youth review was succinct and direct:

I like the part where she explains how she feels about Claire. 
(Least favorite part of the book) Didn't have 1.

I related to her b/c she struggled with her identity like me.

More LGBTQ specifically who like girls.

These two reviews illustrate the importance of context. While review questions did not explicitly emphasize identity categories or feelings of belonging, the overall construction of the library as positioned within the QTY Treehouse's services influenced youth's likelihood of discussing representation. The two reviews provided here reveal an emphasis on identity as experienced in day-to-day life. Specifically, themes of achievement, access, struggle, identity formation, and the lack of representation are prominent in these reviews. Although the QTY Treehouse library collection was designed to include a range of identities within the umbrella of queer and trans representation, youth still hoped for greater and better representation.

Readers should understand youth's desire for more materials in relation to the larger library collection. This illustrates the awareness of both the general shortage of materials and the limited possibilities resulting from institutional oppression, including limitations of publishing.

\section{Conclusion}

The QTY Treehouse library collection is one example of how critical approaches to culturally sensitive spaces and representative materials can inform the creation of a meaningful library collection for youth who experience daily forms of institutional oppression. This analysis of the necessity and success of the collection centers on visibility and representation. The creation of the QTY Treehouse library collection in a culturally sensitive space was an intentional act of addressing forces of policing, criminalization, and institutional oppression that constrain the dayto-day experiences of youth of color and/or LGBTQ and gender non-conforming youth. These forces also act to invisibilize youth from their neighborhoods and to obscure consistent and meaningful portrayals of their lives. The culturally competent and critically informed services the QTY Treehouse provided to LGBTQ and gender non-conforming youth of color created the frame for the incorporation of a broadly representative YA library collection that proclaimed the presence of individual LGBTQ and gender non-conforming youth of color and spoke to the possibilities for collectivity.

Using passive research methods, such as an anonymous half-sheet review form, may have limited the amount of information provided by youth at the QTY Treehouse. Nonetheless, the feedback that was received was meaningful and resonated with thoughts and ideas of the research team.

This research provides a model for collection development practices that help to develop resources, services, and spaces for marginalized and oppressed groups of people. Beyond collection development, positioning the library within a variety of services for LGBTQ and gender non-conforming youth of color created a holistic approach to the service population. As a result, the research reaffirmed the importance of actively engaging the service population in collection development activities.

Moreover, it showed that non-for-profit organizations, especially those focused on social change and social justice, can benefit from the incorporation of library collections and services, especially if collection building practices are oriented toward empowerment and engagement. Partnerships with librarians and libraries willing to engage in shared inquiry can create a sense 
of collectivity and relatability. Situated library services can help libraries to improve access to materials for people who experience oppression, remedying the dominance of white, middleclass, hetero- and gender-normative ways of being.

The partnership that supported this study provided an example of working collaboratively to create opportunities for social change. A combination of critical theory, shared inquiry, culturally sensitive spaces, and anti-oppressive holistic practices could serve as a model for working with vulnerable and underrepresented communities. This is a needed area of research within library and information sciences. Future research may explore the role of library programs (such as book discussion groups, author visits, and other moments that facilitate reflection on shared experience) in working toward collective understandings of oppression, survival, and resistance.

\section{Acknowledgements}

Many thanks to my dissertation committee, whose efforts made this article possible: Dr. Christine Jenkins, Dr. Nicole Cooke, Dr. Carol Tilley, Dr. Rae-Anne Montague, and Dr. Soo Ah Kwon.

\section{Endnotes}

\footnotetext{
1 The Black Panthers were one of many revolutionary groups that formed in the 1960s and 1970 s. The group was notable for advocating for Black Power, actively demonstrating the right to armed defense against the police, creating and administrating breakfast and other community programs, and its Ten-Point Program.
}

\section{Appendix: QTY Library Materials}

This collection was selected for representativeness, but it needs to be acknowledged that there were cases in which a portrayal of one character was done well and another deeply flawed. This was balanced through the overall collection and through a practiced awareness of contents as the library collection was made available to youth. For a few of the texts listed (such as What We Left Behind) there was debate among readers about the accuracy of portrayals (including some conversations around the failure of identity portrayals).

Andrews, A., \& Lyon, J. (2014). Some assembly required: The not-so-secret life of a transgender teen. New York: Simon \& Schuster Books for Young Readers.

Bao, Q., \& Yanagihara, H. (Eds.). (2000). Take out: Queer writing from Asian Pacific America. Philadelphia, PA: Temple University Press.

Beam, C. (2011). I am J. New York: Little, Brown.

Bechdel, A. (2007). Fun home: A family tragi-comic. Boston, MA: Houghton Mifflin.

Belge, K., Bieschke, M., \& Robinson, C. (2011). Queer: The ultimate LGBT guide for teens. San 
Francisco: Zest Books.

Bornstein, K., \& Bergman, S. B. (2010). Gender outlaws: The next generation. New York: Seal Press.

Bornstein, K., \& Quin, S. (2006). Hello, cruel world: 101 alternatives to suicide for teens, freaks, and other outlaws. New York: Seven Stories Press.

Brezenoff, S. (2011). Brooklyn burning. Minneapolis, MN: Carolrhoda Books.

Brown, R. M. (2015). Rubyfruit jungle. New York: Bantam.

Conrad, R. (Ed.). (2014). Against equality: Queer revolution, not mere inclusion. Oakland, CA: AK Press.

Cronn-Mills, K. (2012). Beautiful music for ugly children. Woodbury, MN: Flux.

Dole, M. L. (2008). Down to the bone. Tallahassee, FL: Bella Books.

Eugenides, J. (2002). Middlesex. New York: Picador.

Farizan, S. (2014). Tell me again how a crush should feel. New York: Algonquin Young Readers.

Fu, K. (2014). For today I am a boy. Boston, MA: Houghton Mifflin Harcourt.

Golio, L., \& Scholl, D. (2014). We are the youth. New York: Space-Made.

Goode, L. (2011). Sister mischief. Somerville, MA: Candlewick Press.

Gomez, J. (1991). The Gilda stories. Ann Arbor, Ml: Firebrand Books.

Gregorio, I. W. (2015). None of the above. New York: Balzer \& Bray.

Hern, M. (Ed.). (2012). Stay solid! A radical handbook for youth. Oakland, CA: AK Press.

Hill, K. R., \& Schrag, A. (2014). Rethinking normal: A memoir in transition. New York: Simon \& Schuster Books for Young Readers.

Hopkinson, N. (2015). Falling in love with hominids. San Francisco, CA: Tachyon.

Jarrar, R. (2008). A map of home. New York: Other Press.

Johnson, A. D. (2013). The summer prince. New York: Scholastic.

Keen, L. (2007). Out law: What LGBT youth should know about their legal rights. Boston, MA: Beacon Press.

King, N. (2014). Queer and trans artists of color: Stories of some of our lives. Wilmington, DE: Createspace.

Kuklin, S. (2014). Beyond magenta: Transgender teens speak out. Somerville, MA: Candlewick Press. 
Levithan, D. (2013). Two boys kissing. New York: Knopf Books for Young Readers.

Little, A. (2013). Anatomy of a girl gang. Vancouver: Arsenal Pulp Press.

Lo, M. (2009). Ash. New York: Little, Brown Books for Young Readers.

London, A. (2013). Proxy. New York: Philomel Books.

London, A. (2014). Guardian. New York: Philomel Books.

Lowry, S. (2015). Lost boi. Vancouver: Arsenal Pulp Press.

Marcus, E. (2013). What if? Answers to questions about what it means to be gay and lesbian. New York: Simon Pulse.

Mogul, J. L., Ritchie, A. J., \& Whitlock, K. (2011). Queer (in)justice: The criminalization of LGBT people in the United States. Boston, MA: Beacon Press.

Moon, S. (Ed.). (2012). The letter Q: Queer writers' notes to their younger selves. New York: Arthur A. Levine Books.

Moore, P. (2007). Hero. New York: Disney-Hyperion.

Moskowitz, H. (2015). Not otherwise specified. New York: Simon Pulse.

Neal, J. (2015). What color is your hoodie? Essays on Black gay identity. New York: Chelsea Station Editions.

Newlevant, H. (2014). If this be sin. Brooklyn, NY: Newlevant Comix.

Peters, J. A. (2004). Luna. New York: Little, Brown Books for Young Readers.

Peters, J. A. (2009). Rage: A love story. New York: Knopf Books for Young Readers.

Quesada, U., Gomez, L., \& Vidal-Ortiz, S. (Eds.). (2015). Queer brown voices: Personal narratives of Latina/o LGBT activism. Austin, TX: University of Texas Press.

Quintero, I. (2014). Gabi: A girl in pieces. El Paso, TX: Cinco Puntos Press.

Revoyr, N. (1997). The necessary hunger. New York: St. Martin's Griffin.

Ruff, S. S. (2008). Finlater. New York: Quote Editions.

Sáenz, B. A. (2009). Last night I sang to the monster. El Paso, TX: Cinco Puntes Press.

Sáenz, B. A. (2012). Aristotle and Dante discover the secrets of the universe. New York: Simon \& Schuster Books for Young Readers.

Satyel, R. (2009). Blue boy. New York: Kensington Books.

Stevenson, N. (2015). Nimona. New York: Harper Collins. 
Stryker, S. (2008). Transgender history. New York: Seal Press.

Talley, R. (2014). Lies we tell ourselves. Don Mills, ON: Harlequin Teen.

Talley, R. (2015). What we left behind. Don Mills, ON: Harlequin Teen.

Tamaki, M., \& Tamaki, J. (2008). Skim. Toronto: Groundwood Books.

Tea, M., \& McCubbin, L. (2004). Rent girl. San Francisco: Last Gasp.

Tolbert, T.C., \& Peterson, T. (Eds.). (2013). Troubling the line: Trans and genderqueer poetry and poetics. Callicoon, NY: Nightboat Books.

Wise, T. (2012). Street dreams. New York: Bold Strokes Books.

Woodson, J. (1997). The house you pass on the way. New York: Delacorte Books for Young Readers.

Yee, P. (2011). Money boy. Toronto: Groundwood Books.

\section{References}

Austin, J. (2018). Restorative justice as a tool to address the role of policing and incarceration in the lives of youth in the United States. Journal of Librarianship and Information Science, Sage OnlineFirst.

Bajko, M. S. (2014, July 2). Oakland awards $\$ 1.3 M$ for LGBTQ youth programs. The Bay Area Reporter. Retrieved from https://www.ebar.com/244600

Bernstein, N. (2014). Burning down the house: The end of juvenile prison. New York: New Press.

Beier, E. (n.d.). Store: I like your headband: A first crush story. Retrieved from http://www.elizabethdrewyou.com/store/i-like-your-headband-a-first-crush-story

Bishop, A. P., Mehra, B., Bazzell, I., \& Smith, C. (2003). Participatory action research and digital libraries: Reframing evaluation. In A. P. Bishop, N. A. Van House, \& B. P. Buttenfield (Eds.), Digital library use: Social practice in design and evaluation (pp. 161-189). Cambridge, MA: MIT Press.

Blake. (2015). Blake, 17, Charlotte, NC. Retrieved from http:// wearetheyouth.org/profiles/blake-17-charlotte-nc/

Brown, T. M., \& Rodriguez, L. F. (2009). Issue editors' notes. New Directions for Youth Development: Theory, Practice, Research, 123, 1-9.

Cai, M. (2002). Multicultural literature for children and young adults: Reflections on critical issues. Westport, CT: Greenwood Press.

Cart, M., \& Jenkins, C. A. (2015). Top 250 LGBTQ books for teens: Coming out, being out, and 
the search for community. Chicago, IL: Huron Street Press.

Cassell, H. (2016, May 4). Youth-led confab draws 100 to Oakland. The Bay Area Reporter. Retrieved from https: //www.ebar.com/news/246243

Cheney, A. (2015, February 4). Top 2015 titles for youth in custody-or in your libraries. School Library Journal. Retrieved from http://www.slj.com/2015/02/industry-news/top2015-titles-for-youth-in-custody-or-in-your-libraries/\#_

Collins, P. H. (2008) Black feminist thought: Knowledge, consciousness, and the politics of empowerment. Boston, MA: Unwin Hyman.

Cooke, N. A. (2017). Information services to diverse populations: Developing culturally competent library professionals. Santa Barbara, CA: ABC-CLIO.

Crenshaw, K. (1991). Mapping the margins: Intersectionality, identity politics, and violence against women of color. Stanford Law Review, 43, 1241-1299

Curry, A. (2005). If I ask, will they answer? Evaluating public library reference service to gay and lesbian youth. Reference \& User Services Quarterly, 45(1), 65-75.

Davis, A. (2003). Are prisons obsolete? New York: Seven Stories Press.

Freire, P. (2008). Pedagogy of the oppressed, 30 th anniversary edition. New York: Continuum.

Golio, L., \& Scholl, D. (Eds.). (2014). We are the youth. New York: Space-Made.

Harris, R. (2010, March 16). 'Finlater' by Shawn Stewart Ruff [Book review]. Lambda Literary. Retrieved from http://www.lambdaliterary.org/reviews/ya/03/16/finlater-shawnstewart-ruff/

Harris, V. J. (2003). The complexity of debates about multicultural literature and cultural understanding. In D L. Fox \& K G. Short (Eds.), Stories matter: The complexity of cultural authenticity in children's literature (pp. 3-24). Urbana, IL: National Council of Teachers of English.

Health Initiatives for Youth. (2016). Retrieved from https://hi4youth.org/

Hunt, J., \& Moodie-Mills, A. C. (2012). The unfair criminalization of gay and transgender youth: An overview of the experiences of LGBT youth in the juvenile justice system. Washington, DC: Center for American Progress. Retrieved from https://www.americanprogress.org/issues/lgbt/reports/2012/06/29/11730/the-unfaircriminalization-of-gay-and-transgender-youth/

Jeltsen, M. (2015, March 25). Transgender teen who was crowned homecoming king dies. Huffington Post. Retrieved from http://www. huffingtonpost.com/2015/03/25/transgender-teen-who-was_n_6941780.html

Jiménez, L. (2015). Representations in award-winning LGBTQ young adult literature from 20002013. Journal of Lesbian Studies, 19(4), 406-422. 
Kann, L., O'Malley Olsen, E., McManus, T., Harris, W. A., Shanklin, S. L., Flint, K. H., . . Z Zaza, S. (2016). Sexual identity, sex of sexual contacts, and health-related behaviors among students in grades 9-12 - United States and selected sites, 2015. Morbidity and Mortality Weekly Report, Centers for Disease Control and Prevention, 65(9), 1-202.

Kurz, J. (2018). Out of the closet, but not on the shelf: Questions and concerns about collection development of LGBT books for teens. Young Adult Library Services, 16(4), 20-23.

Kwon, S. A. (2013). Uncivil youth: Race, activism, and affirmative governmentality. Durham, NC: Duke University Press.

Larrick, N. (1965, September 11). The all-white world of children's books. Saturday Evening Review, 63-65.

Little, A. (2013). Anatomy of a girl gang. Vancouver: Arsenal Pulp Press.

Lo, M. (2014). Book challenges suppress diversity. Retrieved from http://www.diversityinya.com/2014/09/book-challenges-suppress-diversity/

Lo, M. (2015). Perceptions of diversity in book reviews. Retrieved from http://www.diversityinya.com/2015/02/perceptions-of-diversity-in-book-reviews/

McCurdy, J. (2014). Targets for arrest. In A.J. Nocella II, P. Parmar, \& D. Stovall (Eds.), From education to incarceration: Dismantling the school-to-prison pipeline (pp. 86-101). New York: Peter Lang.

McIntyre, A. (2008). Participatory action research. Thousand Oaks, CA: Sage Publications.

Mehra, B. (2011). Integrating LGBTIQ representations across the Library and Information Science curriculum: A strategic framework for student-centered interventions. In E. Greenblatt (Ed.), Serving LGBTIQ library and archives users: Essays on outreach, service, collections and access (pp. 298-309). Jefferson, NC: McFarland.

Mehra, B., \& Braquet, D. (2011). Progressive LGBTQ reference: Coming out in the 21st century. Reference Services Review, 39(3), 401-422.

Mehra, B. (2015). Introduction. Library Trends, 64(2), 179-197.

Meiners, E. (2007). Right to be hostile: Schools, prisons, and the making of public enemies. New York: Routledge.

Montague, R. (2015). Mix IT up! A blending of community informatics and youth services librarianship to further social justice in library and information science education. Library Trends, 64(2), 444-457.

Morris, M. W. (2016). Pushout: The criminalization of Black girls in schools. New York: New Press.

Naidoo, J. C., \& Dahlen, S. P. (Eds.). (2013). Diversity in youth literature: Opening doors through reading. Chicago, IL: American Library Association. 
Neal, J. (2015). What color is your hoodie? Essays on Black gay identity. New York: Chelsea Station Editions.

Osher, D. M., Quinn, M. M., Poirier, J. M., \& Rutherford, R. B. (2003). Deconstructing the pipeline: Using efficacy, effectiveness, and cost-benefit data to reduce minority youth incarceration. New Directions for Youth Development, 2003(99), 91-120.

Ostenson, J., Ribeira, R., Wadham, R., \& Irion, K. (2016). Hunky cajuns and gay sextons: Diversity as represented in adolescent book reviews. Journal of Research on Libraries \& Young Adults, 7(3), 1-15.

Phaneuf, W. (2012, November 8). New LGBTQ youth center, QTY Treehouse, opens Friday. East Bay Express. Retrieved from http://www.eastbayexpress.com/CultureSpyBlog/archives/2012/11/08/new-lgbtqyouth-center-qty-treehouse-opens-friday

QTY. (2013, September 5). We're back! QTY 2.0 re-launch! Retrieved from https://www.facebook.com/events/652560311430278/

Roberto, K. R. (2011). Inflexible bodies. Journal of Information Ethics, 20(2), 56-64.

Roberts, S., \& Noble, S. U. (2016). Empowered to name, inspired to act: Social responsibility and diversity as calls to action in the LIS context. Library Trends, 64(3), 512-532.

Robinson, T. (2016). Overcoming social exclusion in public library services to LGBTQ and gender variant youth. Public Library Quarterly, 35(3), 161-174.

Ruff, S. S. (2008). Finlater. New York: Quote Editions.

Schlesselman-Tarango, G. (2016). The legacy of Lady Bountiful: White women in the library. Library Trends, 64(4), 667-686.

Shelton, J., \& Winkelstein, J. (2014). Librarians and social workers: Working together for LGBTQ youth. Young Adult Library Services, 13(1), 20-23.

Sims, R. (1982). Shadow and substance: Afro-American experience in contemporary children's fiction. Urbana, IL: National Council of Teachers of English.

Sims Bishop, R. (1990). Mirrors, windows, and sliding glass doors. Perspectives, 1(3), ix-xi.

Skiba, R. J., Michael, R. S., Nardo, A. C., \& Peterson, R. L. (2000). The color of discipline: Sources of racial and gender disproportionality in school punishment. The Urban Review, 34(4), 317-342.

Spade, D. (2011). Normal life: Administrative violence, critical trans politics and the limits of law. Cambridge, MA: South End Press.

Spiteri, L. F., \& Pecoskie, J. (2016). In the readers' own words. Reference \& User Services Quarterly, 56(2), 91-95.

Stanley, E., \& Smith, N. (Eds.). (2011). Captive genders: Trans embodiment and the Prison 
Industrial Complex. Oakland, CA: AK Press.

Tatum, A. W. (2006). Engaging African American males in reading. Educational Leadership, 63(5), 44-49.

Tatum, A. W. (2008). Toward a more anatomically complete model of literacy instruction: A focus on African American male adolescents and texts. Harvard Educational Review, 78(1), 155-180.

Wald, J., \& Losen, D. (2003). Defining and redirecting a school-to-prison pipeline. New Directions for Youth Development, 2003, 99, 9-15.

WeNeedDiverseBooks. (n.d.). Retrieved from http://weneeddiversebooks.org/

Winn, M. (2011). Girl time: Literacy, justice, and the school-to-prison pipeline. New York: Teacher's College Press.

Jeanie Austin (Jeanie.L.Austin@gmail.com) is a librarian with San Francisco Public Library's Jail \& Reentry Services program. They were formerly the project manager for Mix It Up, an IMLSfunded project at the iSchool at the University of Illinois, Urbana-Champaign. Their interests include the provision of library services to people held in state custody and the gendered, racialized, and ability-centric political and social systems that surround this work. 